研究室紹介

\section{東京大学大学院工学系研究科 マテリアル工学専攻 環境システム工学講座 （足立・松野研究室） \\ Ecology System for Material Science Department of Materials Engineering, Graduate School of Engineering The University of Tokyo}

本研究室は、足立芳寛教授、松野泰也助教授、醍醐市朗 助手の 3 名の個性豊なスタッフと、社会人博士課程の大学 院生 1 名、研究生 1 名、修士課程の大学院生 8 名、学部生 3 名、秘書 4 名の計 20 名の鉄の結束を持った体制で研究をす すめています。本研究室では、持続可能な社会の構築に向 けて、マクロな視点から技術開発や社会システムを設計す ることを目指し、研究に励んでいます。

はじめに

1997年にライフサイクルアセスメント (Life Cycle Assessment; LCA) がISO14040として国際標準化され、 今や先進的企業では、自社製品を評価し、エコラベルや環 境報告書に情報を公開する取組みや、評価結果を設計段階 にフィードバックする取組みをおこなっています。このよ うに、製品評価のツールとしてのLCA はほぼ完成し、製 品の新旧比較では環境負荷量の削減は進んでいると言え ます。しかしながら、少なくとも日本全体でみると、二 酸化炭素の排出量は、京都議定書の目標值である1990年 比 $6 \%$ 削減どころか、1990年比で増加しており、社会全体 での環境影響評価が必要になってきています。そこで、本 研究室では、1つの製品やサービスの評価ではなく、社会 に存在する製品群を評価対象に、それらの時系列の中での 動的な分析ができるLCAに基づいた手法を開発していま す。これは、いくつかの分析手法をLCAと統合させるこ とにより、LCAを時間的空間的に拡張した手法で、技術 開発や社会システムを戦略的に設計することを目的として いるので、戦略的統合化ライフサイクルアセスメント手法 (Strategic Integrated LCA Technology; Silt)と名づけて います。さらに、新素材の開発に携わる研究室が数多く在 籍しているマテリアル工学専攻に籍を置いている優位性か ら、製品のライフサイクルだけでなく、素材のライフサイ クルを考虑した評価手法の開発を試みています。特に、素 材のライフサイクルにおいて問題となるのが、リサイクル であり、素材のマテリアルフロー全体を考慮した上で、さ らにリサイクルの質を考慮した評価手法の構築が、本研究 室の主要なテーマとなっています。その他にも、本研究室

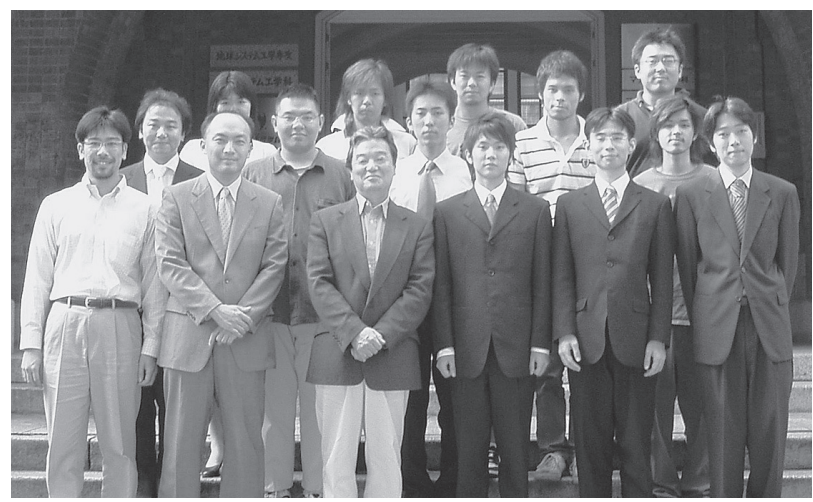

図1足立・松野研究室メンバー

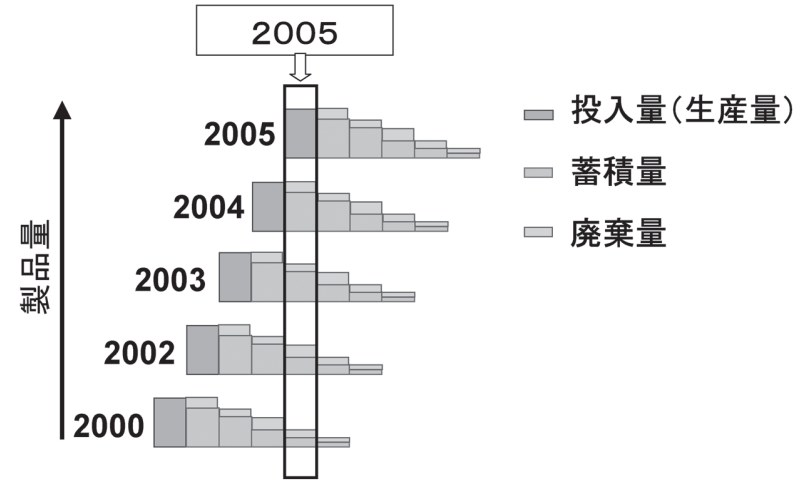

図2 ポピュレーションバランスモデル (PBM)の概念図

では、いくつかの興味深いテーマについて研究を進めてい ます。本稿では、現在おこなわれている研究テーマを $3 つ$ に分類し、それらの概略を説明します。

【研究テーマ1：素材品位を考慮した素材リサイクル評価 モデルの構築】

従来のLCAの評価対象であった製品やサービスのライ フサイクルだけでなく、素材のライフサイクルを考慮した 評価手法の開発を試みています。製品のライフサイクルに おける問題の 1 つに、リサイクルにおけるアロケーション がありますが、素材のライフサイクルを考慮することによ り、リサイクル時の評価に対しても新たな知見を得られる と考えています。

本研究室では、素材のマテリアルフロー全体を評価対象 とするため、ポピュレーションバランスモデル (Population Balance Model; PBM)、ピンチ解析 (Pinch Analysis)、 マテリアルフロー分析／物質フロー分析 (Material Flow Analysis: MFA / Substance Flow Analysis: SFA)などの ッールを、LCA と統合させることによる評価をおこなっ ています。PBMは、ある製品群を考え、当該年以前の消 費量の履歴と当該製品の寿命分布から、当該年における社 会存在量と社会からの使用済久製品発生量を推計する手法 です。図 2 に、2000年から 2005 年の消費量とそれらの寿 命分布を用いた、2005年の社会存在量と使用済み製品発 生量の導出手法を概念的に示しています。これにより、動 

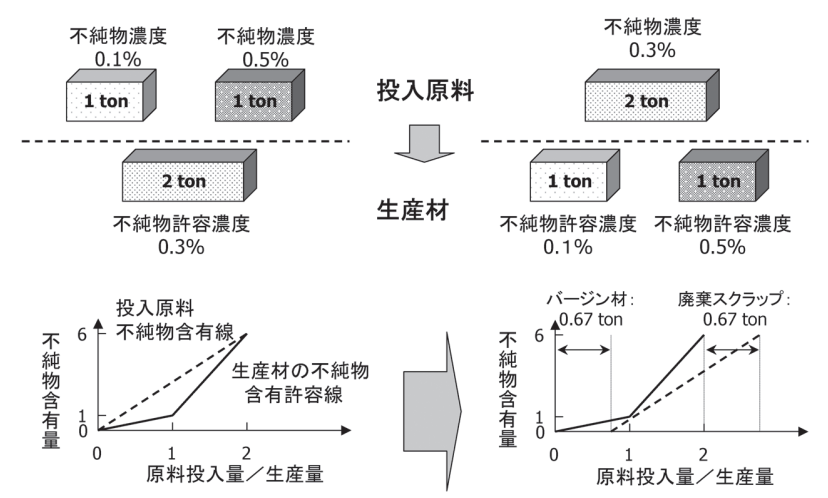

図 3 ピンチ解析概念図

的モデルを構築することができるとともに、回収された使 用済み製品に未回収分も含んだ使用済及製品発生量という 実態の把握が困難な量が推計值として得られます。次に、 ピンチ解析は、リサイクル原料の質と量をともに考慮し、 需要(生産材)の要求する質と量を満たすためにリサイクル 原料を最適配分する手法です。図 3 に、投入原料から生産 材の不純物許容濃度を満たす材を生産できる場合と、でき ない場合の、2つの例におけるピンチ解析による表現を示 しています。できない場合には、不純物を含まないヴァー ジン材の必要量が得られます。これにより、分別工程での 精緻解体などによるリサイクル原料の品位向上のための取 組みによる効果を推計することができます。なお、PBM とピンチ解析に関しては、当研究室スタッフの記した書籍 (足立ら, 環境システム工学, 東京大学出版会, 東京, 2004) に詳しく説明されています。MFA/SFAは、素材や物質 の投入量や排出量を積み上げ、その収支を分析する手法で す。完全なマテリアルフローが把握された素材はほとんど ないため、解析に必要なデー夕が統計值などから得られな い場合に、MFA/SFAを用いて導出します。素材のマテ リアルフロー全体を評価するためには不可欠なッールです。 本研究室では、このようなツールをLCA と統合するこ とにより、素材では、鉄鋼材、プラスチックなどを、製品 では、エアコン、自動車などを評価対象に研究をしてきて おります。

【研究テーマ $2:$ 消費構造やプロセスの最適化モデルの構 築】

従来のLCAにおいては、評価対象の製品ライフサイク ル中のプロセスが、物質の循環を含むなど複雑なプロセ スであった場合、インベントリを積み上げるのが困難でし た。同様に、素材ライフサイクルを評価する際に、開ルー プリサイクルにより利用されている素材のリサイクルを解 析するのも困難でした。そこで、本研究室では、それらを 解析できる行列を用いた手法を開発しています。複雑なプ ロセスを含む製品やサービスの評価には、マトリックス法

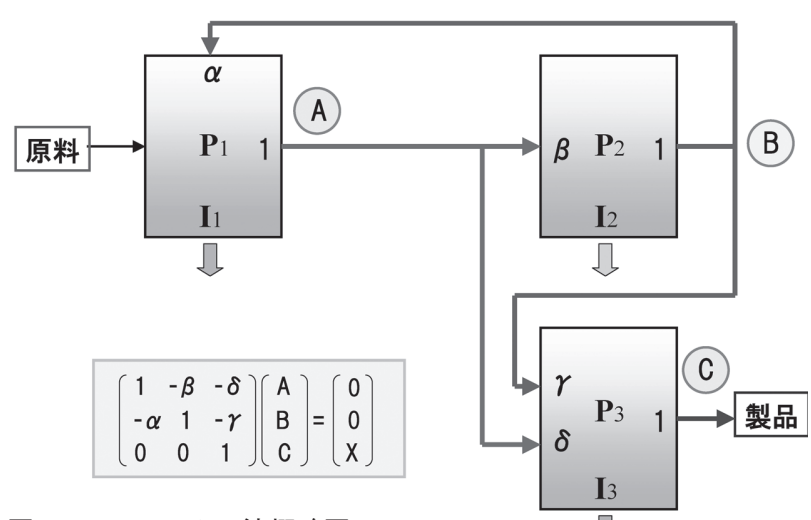

図4 マトリックス法概略図

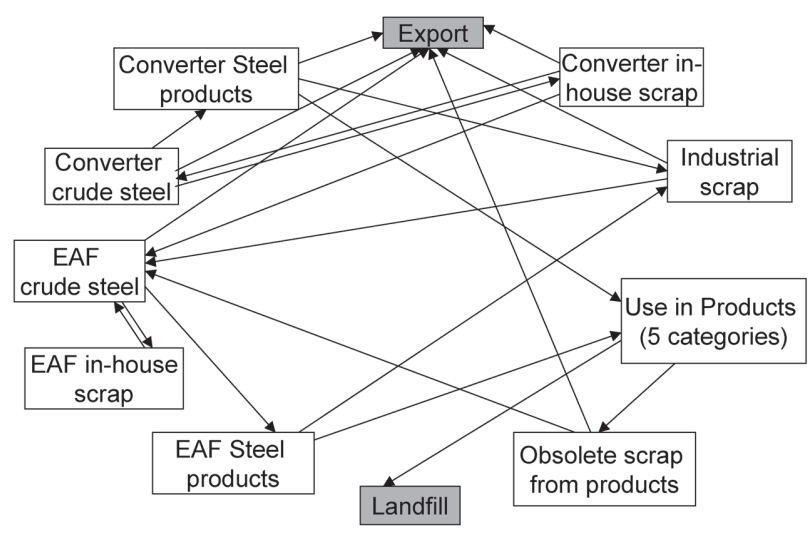

図 5 鉄鋼マテリアルフローを状態遷移により表した図

を適用し、開ループリサイクルの解析には、マルコフ連鎖 モデル (Markov Chain Model)を適用した評価手法を開発 しています。

マトリックス法は、評価対象製品のインベントリをさか のぼると循環するプロセスがある場合、循環するプロセス の機能単位あたりのプロセス量を、行列計算を用いること により容易に導出する手法です。例えば、眓 4 に示すよう なプロセスを考えたとき、プロセス P1とP2において、物 質が循環しているのがわかります。図4のように単純なプ ロセスであれば、まだ積上げ法により導出できるが、これ らプロセスが複雑になればなるほど、積上げ法では煩雑な 計算が必要となります。な扔、実際の計算においては、東 京大学大学院工学系研究科機械工学専攻の酒井研究室で開 発されたツール”EMLCA”を用いることによりマイクロ ソフトExcelを用いて容易に解析できます。(http://irwin.t. u-tokyo.ac.jp/ sakai/soft/LCA/LcaExcel.htmにて入手可)

次に、マルコフ連鎖モデルは、確率過程論におけるモデ ルで、状態間の遷移確率により現象の変遷を解析するッー ルです。開ループリサイクルにより利用されている鉄鋼材 などの素材のリサイクルを解析するのに適応することがで きます。図 5 に、鉄鋼材のマテリアルフローを状態間の確 率過程により表した模式図を示します。フロー量を状態間 の推移確率に変換し、確率過程論を用いることで、素材が 社会中で何回利用され、何年滞留しているのかを解析する 
ことができます。

【研究テーマ3：新技術の導入による環境負荷削減効果の 評価モデルの構築】

従来のLCAにおいては、既存の製品やサービスを対象 とした評価が主流でしたが、今後の社会を設計するため には、持続型社会の構築に貢献する新たな技術導入による 環境負荷削減効果を評価する必要があります。そこで、本 研究室では、産業間連携(エコ・コンビナート)による環境 負荷削減効果と、ICT (Information and Communication Technology）の利用による環境負荷削減効果の導出を試み ています。

また、先述のような製品やサービスのライフサイクルだ けでなく、素材のライフサイクルを考慮した評価手法が開 発されたことにより、新技術の導入による環境負荷削減効 果を導出することが可能になった例もあります。例えば、 自動車に易解体設計を導入したことにより、品位の高い鉄 スクラップがELV (End-of-life Vehicle) から排出されるこ とが予想され、それにより鉄鋼材における天然資源の使用 量が減少し、鉄鋼材生産時の環境負荷が削減されると考え られます。このように、自動車の製造技術でありながら、 鉄鋼材製造にかかる環境負荷に間接的に影響を与えるよう な事例の環境負荷削減効果を導出することが可能になりま す。

\section{まとめ}

最小の環境負荷で最大の効用を得るシステムを構築する ためには、個々の製品やプロセス毎の計測のみならず、社 会に組み合わせて適用することにより、社会システム全体 としての効用を計測し、社会システム全体としてょり効率 を高く、社会システム全体の効用を最大化するための評価 手法が必要である。ISO-LCA 手法を基礎に、製品、プロ セスの組み合わせの社会への普及度に応じた計測を可能と するシミュレーションの手法を、戦略的統合化ライフサイ クルアセスメント手法 (Strategic Integrated LCA Technology; Silt) と位置付け (図 6 )、その具体的適用例が本稿 で述べてきたものである。今後、これらの適用例の拡大と シミュレーション手法としてのツールの更なる開発、社会 の得る効用の規格化、計量化を可能とする手法体系とし て、Silt手法の進化が期待される。このSilt手法は、今後 開発起案される「新たな工学的イノベーション」に基づく製 品システムが、「最小の投資(環境負荷)」で「最大の効果 (社 会的効用)」を与えるものかどうかの定量的示唆を与える評 価手法として重要な役割を果たすと期待される。

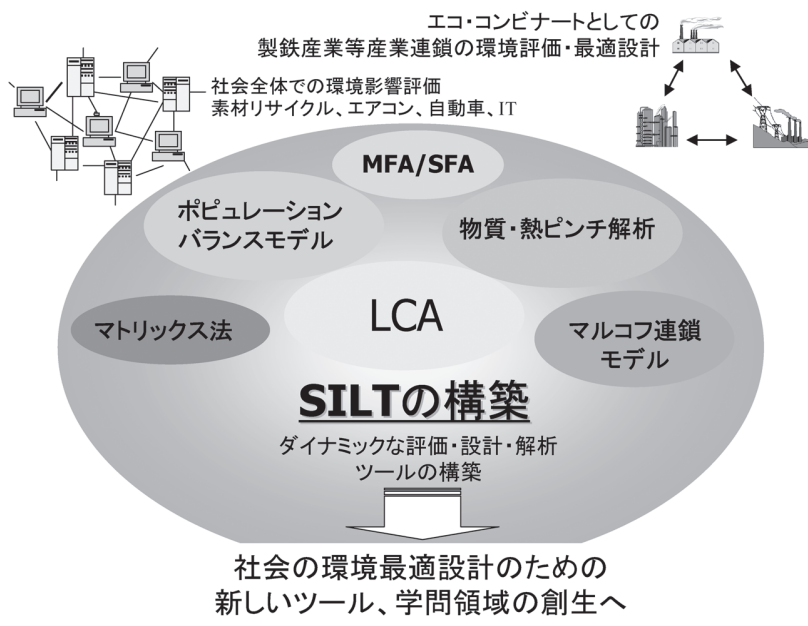

図6 戦略的統合化ライフサイクルアセスメント手法 (Strategic Integrated LCA Technology; Silt) 概念図

\section{著者: 足立 芳寛·松野 泰也. 醍醐 市朗·瀧口博明 東京大学出版会 2004年4月15日発刊

第1章 地球環境問題
第2章 環境亡社会
第3章 環境評価手法一LCA
第4章 LCA手法の拡大
第5章 まとめ

図 7 教科書『環境システム工学』

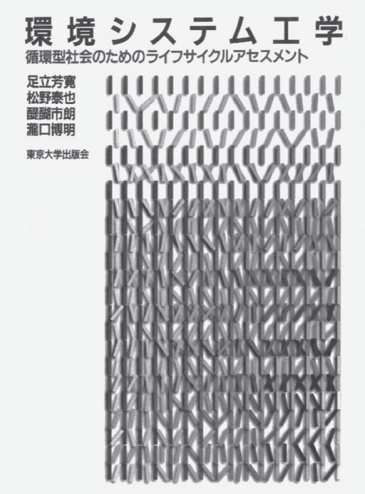

PBMとピンチ解析の説明時に紹介した書籍 (足立ら, 環 境システム工学, 東京大学出版会, 東京, 2004) は、当研究 室スタッフが本学での講義の際に、教科書としても利用 しています。1章は、地球環境問題の経緯と現状につい て、2章は、環境政策、主に経済的措置について、3章は、 LCAについて基礎から学べる内容となっています。最後 に、4章は、応用編であり、上述したようなSilt手法につ いて、概念からエクセルを使った実計算手法まで記され、 当該分野の研究者を目指す学生には、必携の図書と自負し ています。(図7) 